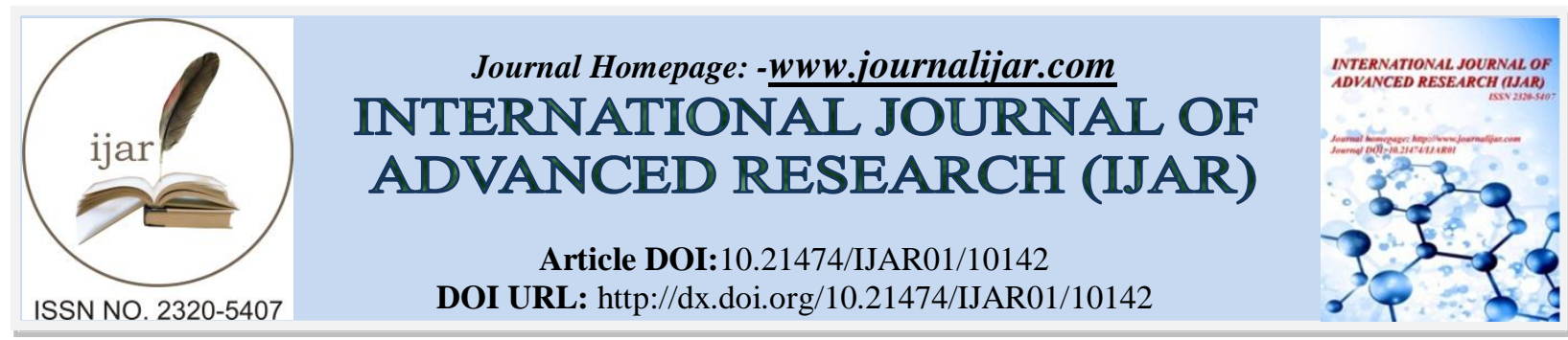

RESEARCH ARTICLE

\title{
SENSITIVITY OF ALTERNARIA ALTERNATA AGAINST CARBENDAZIM CAUSING FRUIT ROT OF POMEGRANATE.
}

Bharade S. S. ${ }^{1}$ and Kamble S. $\mathbf{S}^{2}$.

1. Department Of Botany, Badrinarayan Barwale Mahavidyalaya Jalna. Dr. Babasaheb Ambedkar Marathwada University, Aurangabad. 431203.

2. Mycology and Plant Pathology Laboratory, Department Of Botany, Shivaji University, Kolhapur. 416004.

\section{Manuscript Info}

\section{Manuscript History}

Received: 01 October 2019

Final Accepted: 03 November 2019

Published: December 2019

Key words:-

Alternaria alternata, Carbendazim,

Isolate, Pomegranate fruit.

\section{Abstract}

It was found that there was variation in the MIC of carbendazim among 21 isolates of Alternaria alternata (Fr.) Keissler on agar plates and on pomegranate fruits. MIC on agar plates ranged from 500 to 1000 $\mu \mathrm{g} / \mathrm{ml}$ and $\mathrm{Ed}_{50}$ from 325.33 to $693.75 \mu \mathrm{g} / \mathrm{ml}$, while it was 100 to 350 $\mu \mathrm{g} / \mathrm{ml}$ and $\mathrm{Ed}_{50} 33.76$ to $136.48 \mu \mathrm{g} / \mathrm{ml}$, on fruits Collected from Kolar (Dist. Ahmednagar), Parali (Dist. Beed), Mahabaleshwar (Dist. Satara), Rahuri (Dist. Ahmednagar) and Sangli. It appears that with the increase of the concentration of fungicide in the medium and on the pomegranate fruits there was decrease in the radial growth of the pathogen.

Copy Right, IJAR, 2019,. All rights reserved.

\section{Introduction:-}

Pomegranate (Punica granatum L.) is one of the important fruits in our country. It is grown in tropical and subtropical regions of the world. Pomegranate is grown as commercial crop in India. In Maharashtra many farmers are growing pomegranate. Pomegranate fruits are taken in all the three seasons but recently due to change in climatic conditions and storage the crop is attacked by many fungal pathogens (Padule and Kaulgud, 1993). Among the fungal pathogens Alternaria alternata was very common (Bharade and Kamble, 2001).The disease caused by Alternaria alternata to pomegranate fruit is managed by using carbendazim. The present investigation was carried out to determine the minimum inhibitory concentration of carbendazim for effective disease management.

\section{Material and Method:-}

Twenty one Fruit samples exhibiting fruit rot of pomegranate were collected from different fruit markets and surrounding of pomegranate fields of Ahmednagar, Rahuri, Kolhapur, Aurangabad, Sangli, Parbhani, Gangakhed, Kolhapur, Beed, Jalna, Pandharpur, Shrirampur, Yavatmal, Latur (Ausa), Parali, Mahabaleshwar and Sangli districts of Maharashtra. To isolate the causal agent, they were brought to the laboratory in clean sterilized polythene bags. The infected portion of fruit is cut in to the size $2 \mathrm{~mm}$ and sterilized by using $0.1 \% \mathrm{HgCl} 2$ and washed with sterilized distilled water (Jadhav et al., 2010), these sterilized fruit portion were kept on a Czapek dox agar plates amended with streptomycin sulphate (Patil et al., 2012; Mali et al., 2015). Inoculated plates were incubated at $28 \pm$ $20 \mathrm{C}$ for growth of the fungus and further studies (Mali et al., 2016). After 9-10 days of culture, greyish fungal mass was observed. On the basis of morphological, microscopic characters and following relevant mycological literature the fungal isolate was identified as Alternaria alternata (Fr.) Keissler. In this manner, 21 isolates were obtained. In vitro and in vivo sensitivity (MIC) of Alternaria alternata (Fr.) Keissler and $\mathrm{ED}_{50}$ of carbendazim was carried out by

Corresponding Author:- Bharade S. S.

Address:- Department Of Botany, Badrinarayan Barwale Mahavidyalaya Jalna. Dr. Babasaheb Ambedkar Marathwada University, Aurangabad. 431203. 
using Food Poisoning Technique (Dekker and Gielink, 1979). Czapek Dox agar medium plates were prepared containing different concentrations of carbendazim. After solidification of media, a disc $(8 \mathrm{~mm})$ with fungal culture was obtained from the margin of an actively growing colony and placed upside down on the agar surface. These plates were then incubated at $28-30^{\circ} \mathrm{C}$ in 12 hour cycle of dark and light and then continuous growth was measured after various time intervals. Plates without carbendazim was served as control. On pomegranate fruits $8 \mathrm{~mm}$ diameter hole having $3 \mathrm{~cm}$ depth was prepared with the help of cork borer and was inoculated with spore suspension of various isolates along with different concentrations (a.i) of carbendazim solution treated before 24 hours. Pomegranate fruits were wrapped with moist paper towels and percent infection was recorded after various incubation periods. From Table 1. and Table 2. again proved that there are six groups in the isolates according to their sensitivity viz., Group - I (Aa-2), Group - II (Aa-3, Aa-4) Group III (Aa-1, Aa-5, Aa-9, Aa-10, Aa-11, Aa14), Group IV (Aa-6, Aa-7, Aa-8, Aa-12, Aa-13), Group V (Aa-15), Group VI (Aa-16, Aa-17, Aa-18, Aa-19, Aa-20, Aa-21). Group first indicates MIC $500 \mu \mathrm{g} / \mathrm{ml}$, Group - II $600 \mu \mathrm{g} / \mathrm{ml}$, Group - III $700 \mu \mathrm{g} / \mathrm{ml}$, Group - IV $800 \mu \mathrm{g} / \mathrm{ml}$, Group V $900 \mu \mathrm{g} / \mathrm{ml}$ and Group - VI $1000 \mu \mathrm{g} / \mathrm{ml}$. Similarly in vivo Group I showed MIC $100 \mu \mathrm{g} / \mathrm{ml}$, Group-II 140 - $150 \mu \mathrm{g} / \mathrm{ml}$, Group-III 200 and group - IV $350 \mu \mathrm{g} / \mathrm{ml}$ MIC respectively. The dose response curves were calculated by means of computer using equation.

Where,

$$
Y=\frac{1}{1+\operatorname{Exp}(\text { at bx })}
$$

1. $\mathrm{Y}=$ radial growth as percent of control

2. $\mathrm{H}=$ upper limit of the curve.

3. Exp. = logarithmic exponent

4. $\mathrm{a}=$ regression constant

5. $\mathrm{b}=$ regression coefficient

6. $\mathrm{x}=$ measured parts by (Molnar et al., 1985).

\section{Result and Discussion:-}

Results are given in Tables 2 and Table 3. It was seen that there was variation in MIC of carbendazim against fruit rot pathogen on agar plates and on pomegranate fruits. MIC on agar plates ranged from 500 to $1000 \mu \mathrm{g} / \mathrm{ml}$ and $\mathrm{Ed}_{50}$ from 325.33 to $693.75 \mu \mathrm{g} / \mathrm{ml}$, while it was 100 to $350 \mu \mathrm{g} / \mathrm{ml}$ and $\mathrm{Ed}_{50} 33.76$ to $136.48 \mu \mathrm{g} / \mathrm{ml}$. Fig 1 and Fig 2 revels that with the increase of the concentration of fungicide in the medium and on the pomegranate fruits there was decrease in the radial growth of the pathogen. The same reports were observed by many workers (Van Tuyl, 1975), In India attention towards fungicide resistance is focused by Gangawane (1981), Annamalai and Lalithakumari (1990). Gangawane and Kamble (1993), Chander and Thind (1995). Putto and Chaudhary (1986).

Table 2:- MIC of Carbendazim against Alternaria alternata causing fruit rot of pomegranate in vitro

\begin{tabular}{|c|c|c|c|c|c|c|c|}
\hline \multirow{3}{*}{$\begin{array}{l}\text { Sr. } \\
\text { No. }\end{array}$} & \multirow[t]{3}{*}{ Isolate } & \multicolumn{6}{|c|}{ Data characteristic to dose response curve } \\
\hline & & \multirow[t]{2}{*}{ Locality } & \multicolumn{2}{|c|}{ Regression } & \multirow{2}{*}{$\begin{array}{l}\text { Correlation } \\
\text { coefficient }\end{array}$} & \multirow{2}{*}{$\begin{array}{l}\mathrm{ED}_{50}{ }^{*} \\
\mu \mathrm{g} / \mathrm{ml}\end{array}$} & \multirow{2}{*}{$\begin{array}{l}\mathrm{MIC}^{* *} \\
\mu \mathrm{g} / \mathrm{ml}\end{array}$} \\
\hline & & & Constant & Coefficient & & & \\
\hline 1 & Aa-1 & Aurangabad & -3.2202 & 0.00 .19 & 0.7735 & 352.33 & 700.00 \\
\hline 2 & Aa-2 & Solapur & -3.7203 & 0.0113 & 0.8073 & 329.72 & 500.00 \\
\hline 3 & Aa-3 & Sangavi & -4.3104 & 0.0127 & 0.8793 & 340.32 & 600.00 \\
\hline 4 & Aa-4 & Parbhani & -3.7989 & 0.0117 & 0.8223 & 325.93 & 600.00 \\
\hline 5 & Aa-5 & Chavani, A'bad & -3.1553 & 0.0092 & 0.7696 & 343.22 & 700.00 \\
\hline 6 & Aa-6 & Osmanabad & -2.8832 & 0.0072 & 0.7391 & 397.79 & 800.00 \\
\hline 7 & $\mathrm{Aa}-7$ & Gangakhed & -2.7813 & 0.0072 & 0.7289 & 385.01 & 800.00 \\
\hline 8 & Aa-8 & Kolhapur & -3.3629 & 0.0075 & 0.7880 & 451.00 & 800.00 \\
\hline 9 & Aa-9 & Ahmednagar & -3.1926 & 0.0079 & 0.7887 & 406.34 & 800.00 \\
\hline 10 & $\mathrm{Aa}-10$ & Beed & -3.0543 & 0.0087 & 0.7443 & 349.50 & 700.00 \\
\hline 11 & Aa-11 & Jalna & -3.1995 & 0.0085 & 0.7494 & 376.24 & 700.00 \\
\hline 12 & Aa-12 & Pandharpur & -2.7520 & 0.0073 & 0.7283 & 377.46 & 800.00 \\
\hline
\end{tabular}




\begin{tabular}{|l|l|l|l|l|l|l|l|}
\hline 13 & Aa-13 & Shrirampur & -3.0820 & 0.0075 & 0.7647 & 412.31 & 800.00 \\
\hline 14 & Aa-14 & Yavatmal & -3.1706 & 0.0088 & 0.7562 & 361.83 & 700.00 \\
\hline 15 & Aa-15 & Padegaon, A'bad & -2.7920 & 0.0060 & 0.7292 & 465.38 & 900.00 \\
\hline 16 & Aa-16 & Ausa, Latur & -2.9349 & 0.0061 & 0.7494 & 477.41 & 900.00 \\
\hline 17 & Aa-17 & Kolar & -2.8890 & 0.0059 & 0.7834 & 485.82 & 1000.00 \\
\hline 18 & Aa-18 & Parali & -2.5417 & 0.0054 & 0.7269 & 473.64 & 1000.00 \\
\hline 19 & Aa-19 & Mahabaleshwar & -2.9317 & 0.0055 & 0.7643 & 536.95 & 1000.00 \\
\hline 20 & Aa-20 & Rahuri & -2.8951 & 0.0055 & 0.7669 & 521.74 & 1000.00 \\
\hline 21 & Aa-21 & Sangali & -3.6508 & 0.0053 & 0.8089 & 693.75 & 1000.00 \\
& & & & & & \\
\hline
\end{tabular}

$\mathrm{ED}_{50}$ Carbendazim cocentration causing 50\% reduction in radial growth

MIC Minimum inhibitory concentration

Table 3:- MIC of Carbendazim against Alternaria alternata causing fruit rot of pomegranate in vivo

\begin{tabular}{|c|c|c|c|c|c|c|c|}
\hline \multirow{3}{*}{$\begin{array}{l}\text { Sr. } \\
\text { No. }\end{array}$} & \multirow[t]{3}{*}{ Isolate } & \multicolumn{6}{|c|}{ Data characteristic to dose response curve } \\
\hline & & \multirow[t]{2}{*}{ Locality } & \multicolumn{2}{|c|}{ Regression } & \multirow{2}{*}{$\begin{array}{l}\text { Correlation } \\
\text { coefficient }\end{array}$} & \multirow{2}{*}{$\begin{array}{l}\mathrm{ED}_{50}{ }^{*} \\
\mu \mathrm{g} / \mathrm{ml}\end{array}$} & \multirow{2}{*}{$\begin{array}{l}\mathrm{MIC}^{* *} \\
\mu \mathrm{g} / \mathrm{ml}\end{array}$} \\
\hline & & & Constant & Coefficient & & & \\
\hline 1 & Aa-1 & Aurangabad & -1.6655 & 0.0440 & 0.6325 & 37.87 & 100.00 \\
\hline 2 & Aa-2 & Solapur & -1.3651 & 0.0404 & 0.5773 & 33.76 & 100.00 \\
\hline 3 & Aa-3 & Sangavi & -2.1738 & 0.0516 & 0.7209 & 42.13 & 100.00 \\
\hline 4 & $\mathrm{Aa}-4$ & Parbhani & -1.6794 & 0.0472 & 0.6581 & 35.61 & 100.00 \\
\hline 5 & Aa-5 & Chavani, A'bad & -2.3340 & 0.0508 & 0.7308 & 45.93 & 100.00 \\
\hline 6 & Aa-6 & Osmanabad & -1.5336 & 0.0325 & 0.3562 & 47.14 & 140.00 \\
\hline 7 & $\mathrm{Aa}-7$ & Gangakhed & -1.4088 & 0.0312 & 0.6689 & 45.16 & 150.00 \\
\hline 8 & Aa-8 & Kolhapur & -1.3621 & 0.0299 & 0.6518 & 45.49 & 150.00 \\
\hline 9 & Aa-9 & Ahmednagar & -1.6155 & 0.0319 & 0.6852 & 50.60 & 150.00 \\
\hline 10 & Aa-10 & Beed & -2.4788 & 0.0281 & 0.7727 & 88.36 & 200.00 \\
\hline 11 & Aa-11 & Jalna & -2.6764 & 0.0295 & 0.7986 & 90.73 & 200.00 \\
\hline 12 & Aa-12 & Pandharpur & -1.8287 & 0.0244 & 0.6806 & 74.87 & 200.00 \\
\hline 13 & Aa-13 & Shrirampur & -1.9365 & 0.0262 & 0.7115 & 73.82 & 200.00 \\
\hline 14 & Aa-14 & Yavatmal & -2.7703 & 0.0411 & 0.7537 & 67.47 & 140.00 \\
\hline 15 & Aa-15 & Padegaon, A'bad & -2.7644 & 0.0292 & 0.8013 & 94.73 & 200.00 \\
\hline 16 & Aa-16 & Ausa, Latur & -1.0641 & 0.0106 & 0.5828 & 100.66 & 350.00 \\
\hline 17 & Aa-17 & Kolar & -1.0680 & 0.0105 & 0.5812 & 101.79 & 350.00 \\
\hline 18 & Aa-18 & Parali & -0.9549 & 0.0104 & 0.5683 & 92.23 & 350.00 \\
\hline 19 & Aa-19 & Mahabaleshwar & -1.7271 & 0.0127 & 0.6615 & 136.48 & 350.00 \\
\hline 20 & Aa-20 & Rahuri & -1.1493 & 0.0109 & 0.6006 & 105.53 & 350.00 \\
\hline 21 & Aa-21 & Sangali & -1.1262 & 0.0127 & 0.6504 & 108.50 & 350.00 \\
\hline
\end{tabular}

* $\mathrm{ED}_{50}$ Carbendazim cocentration causing $50 \%$ reduction in radial growth

** MIC Minimum inhibitory concentration

\section{Reference:-}

1. Annamalai, P. and Lalithakumari, D. (1990). Decreased activity of Drechslera oryzae field isolate to endifenphos. Indian Phytopath. 43(4): 553-558

2. Bharade, S.S. and Kamble S.S. (2001). Post harvest pathogen of pomegranate in Maharashtra Plant Disease Management, 145-147 
3. Chander, M. and Thind, T.S. (1995). Development of carbendazim resistance in Gleosporium ampelophagum and strategies for its management. Ind. J. Mycol. Plant Pathol., 25: pp.25-33.

4. Dekker, J. and Glelink, A.J. (1979a \& b). Acquired resistance to pimaracin in Cladosporium cucumarinum and Fusarium oxysporum f. sp. narcissi associated with decreased virulence. Neth. J. Plant. Pathol. 85: 67-73.

5. Gangawane, L.V. (1981). Fungicide resistance in crop protection. Pesticides 15(11): 12-16.

6. Gangawane, L.V. and Kamble, S.S. (1993). Synergistic effects of fungicides on carbendazim resistance in Macrophomina phaseolina causing charcoal rot of potato. In Proc. WZ Meet of IPS PKV, Akola (Eds. Mayee, C.D. et al.), pp. 62-63.Padule, D.N. and Kaulgud, S.N. (1993). Chemical control of leaf spot and fruit spot of pomegranate (Punica granatum L.), In Chemical management of plant pathogens in Western India, pp. 47-49.

7. Putto, B.L. and Chaudhary, Basu, K.C. (1986). Management of apple scab pathogen resistant to fungicides. Vistas in Plant Pathology, pp. 361-366.

8. Van Tuyl, J.M. (1975). Genetic aspects of resistance to Benomyl and Thiabendazole in a number of fungi, Medel Rijstak Landb. Wetensch. Gent. 50.

9. Jadhav, D. Y., Sahoo, A. K., Ghosh, J. S., Ranveer, R. C. and Mali, A. M. (2010): Phytochemical Detection and in vitro Evaluation of Tamarind Fruit Pulp for Potential Antimicrobial Activity. International Journal of Tropical Medicine. 5(3): 68-72. DOI: 10.3923/ijtmed.2010.68.72.

10. Mali, A. M., Patil, V. B., Ade, A. B., Chavan, N. S. And Kamble, S. S. (2015): First Report Of Fusarium Sp. FIESC 17 On Cucumis trigonus In India. Plant Disease. 10.1094/PDIS -09 -14 -0881 -PDN.

11. Mali, A. M., Patil, V. B., Pise, N. M. and Ade, A. B. (2016): First Report of Leaf Spot Caused by Fusarium sp. NFCCI 2882 on Angiopteris evecta: A King Fern from Western Ghats, India. Plant Disease.

12. Patil, V. B., Mali, A. M., Mahamuni, R. J., Chavan, N. S. And Kamble, S. S. (2012): First Report Of Leaf Spot Caused By Phoma Costarricensis on Delphinium Malabaricum In Western Ghats Of India. Plant Disease. 96:1074.

13. Molnar, A., L. Hornok and Resti, M. (1985). The high level of Benomyl tolerance in Fusarium oxsporum is determined by the synergistic interaction of two games. Extl. Mycol. 9: 326-333. 